\title{
ANTIOXIDANT \\ NUTRIENTS AND \\ IMMUNE FUNCTIONS
}




\section{ADVANCES IN EXPERIMENTAL MEDICINE AND BIOLOGY}

Editorial Board:

NATHAN BACK, State University of New York at Buffalo

IRUN R. COHEN, The Weizmann Institute of Science

DAVID KRITCHEVSKY, Wistar Institute

ABEL LAJTHA, $N$. S. Kline Institute for Psychiatric Research

RODOLFO PAOLETTI, University of Milan

Recent Volumes in this Series

Volume 254

MECHANISMS OF LYMPHOCYTE ACTIVATION AND IMMUNE REGULATION II

Edited by Sudhir Gupta and William E. Paul

Volume 255

CALCIUM PROTEIN SIGNALING

Edited by H. Hidaka

Volume 256

ENDOTOXIN

Edited by Herman Friedman, T. W. Klein, Masayasu Nakano, and Alois Nowotny

Volume 257

THE IMMUNE RESPONSE TO VIRAL INFECTIONS

Edited by B. A. Askonas, B. Moss, G. Torrigiani, and S. Gorini

Volume 258

COPPER BIOAVAILABILITY AND METABOLISM

Edited by Constance Kies

Volume 259

RENAL EICOSANOIDS

Edited by Michael J. Dunn, Carlo Patrono, and Giulio A. Cinotti

Volume 260

NEW PERSPECTIVES IN HEMODIALYSIS, PERITONEAL DIALYSIS,

ARTERIOVENOUS HEMOFILTRATION, AND PLASMAPHERESIS

Edited by W. H. Hörl and P. J. Schollmeyer

Volume 261

CONTROL OF THE THYROID GLAND: Regulation of Its

Normal Function and Growth

Edited by Ragnar Ekholm, Leonard D. Kohn, and Seymour H. Wollman

Volume 262

ANTIOXIDANT NUTRIENTS AND IMMUNE FUNCTIONS

Edited by Adrianne Bendich, Marshall Phillips, and Robert P. Tengerdy

A Continuation Order Plan is available for this series. A continuation order will bring delivery of each new volume immediately upon publication. Volumes are billed only upon actual shipment. For further information please contact the publisher. 


\section{ANTIOXIDANT NUTRIENTS AND IMMUNE FUNCTIONS}

Edited by

Adrianne Bendich

Hoffmann LaRoche, Inc.

Nutley, New Jersey

\section{Marshall Phillips}

Agricultural Research Service, USDA, NADC

Ames, Iowa

and

Robert P. Tengerdy

Colorado State University

Fort Collins, Colorado 
Library of Congress Cataloging in Publication Data

Agricultural and Food Chemistry Division of the American Chemical Society Symposium on Antioxidant Nutrients and the Immune Response (1988: Los Angeles, Calif.)

Antioxidant nutrients and immune functions / edited by Adrianne Bendich, Marshall Phillips, Robert P. Tengerdy.

p. $\quad \mathrm{cm}$. - (Advances in experimental medicine and biology; v. 262)

Includes bibliographical references.

ISBN-13: 978-1-4612-7863-4 e-ISBN-13: 978-1-4613-0553-8

DOI: $10.1007 / 978-1-4613-0553-8$

1. Immunity - Nutritional aspects-Congresses. 2. Antioxidants-Physiological effect-Congresses. 3. Active oxygen-Physiological effect-Congresses. I. Bendich, Adrianne. II. Phillips, Marshall. III. Tengerdy, Robert P. IV. American Chemical Society. Division of Agricultural and Food Chemistry. V. Title. VI. Series.

Proceedings of the Agricultural and Food Chemistry Division of the American Chemical Society Symposium on Antioxidant Nutrients and the Immune Response, held September 29, 1988, in Los Angeles, California

(C) 1990 Plenum Press, New York

Softcover reprint of the hardcover 1st edition 1990

A Division of Plenum Publishing Corporation

233 Spring Street, New York, N.Y. 10013

All rights reserved

No part of this book may be reproduced, stored in a retrieval system, or transmitted in any form or by any means, electronic, mechanical, photocopying, microfilming, recording, or otherwise, without written permission from the Publisher 
Adrianne Bendich dedicates this book to: David, Jorden, and Debra, Joseph, Lillian, and Elaine

Marshall Phillips dedicates this book to: Karen, Tacy, Dori, and Larry

Robert Tengerdy dedicates this book to: Katherine, Thomas, and Peter 


\section{PREFACE}

The determination of optimal nutritional status has traditionally been based upon generalized parameters such as weight gain and body fat levels. Vitamin and mineral requirements were often related to the intakes needed to prevent overt signs of deficiency diseases such as beriberi or scurvy. However, in the past decade or so, there have been intensive investigations to determine the subtle changes in physiological functions associated with marginal micronutrient intakes. There is a growing consensus that immune system activities are very sensitive indicators of micronutrient status. During this decade, there has also been a rapid expansion of research in the role of free radicals and antioxidants in the major chronic diseases which afflict mankind(i.e. cancer, cardiovascular disease, and autoimmune disease).

The main function of antioxidant nutrients in an appropriate diet is the prevention of oxidative damage to cells and their physiological functions. Antioxidant nutrients counteract free radicals and damaging oxidative actions on cell membranes. Since the cells of the immune system are rapidly differentiating and proliferating, such dividing and transforming cells are particularly susceptible to damage by oxidation.

The interactions of antioxidant nutrition and immune system activities and disease resistance are therefore logical areas for research. Thus, the objective of this symposium was to bring together the leading investigators who have examined the immunological effects of dietary essential nutrients which share the capacity to act as antioxidants.

Over the past 15 years, there has been a growing interest in the reproducible adverse effects of the deficiencies of vitamins $C$ and $E$, zinc, selenium or copper deficiency of cellular and humoral responses as well as phagocytic function. Oxidative damage to leukocytes and immunosuppressive effects of prostaglandin E 2, lipid peroxides and conjugated immunoglobulins are possible rationales for immunosuppression associated with antioxidant micronutrient deficiencies. Similarly, many studies have also found immunoenhancement associated with dietary supplementation of the above micronutrients as well as with beta carotene.

Sound nutrition consists of a necessary balance between the various elements of the diet: protein, calories, lipids, vitamins and minerals. The nutritional state of individuals may be a clue that determines immunocompetence and disease resistance. The interest in proper nutrition has moved beyond the scientific laboratory and has reached into the public awareness. The perception of the health consequences of sound nutrition is as important as the scientific validity. Therefore, it is anticipated that the research from the emerging field of nutritional immunology will be seriously considered in the development of nutrition policy. Because of the importance of antioxidant nutritional status and its effects on immunocompetence, further research is recommended with emphasis on clinical and epidemiological areas. 


\section{ACKNOWLEDGEMENTS}

The authors acknowledge the Division of Agricultural and Food Chemistry of the American Chemical Society for sponsoring this symposium at the National meeting in Los Angeles.

Financial contributions and support from Hoffman-LaRoche, Inc., Mead Johnson Nutritional Division, Nabisco Brands, Inc., Quaker Oats Company, and Takeda U.S.A., Inc., are sincerely acknowledged.

We appreciate the technical assistance of Ms. Janice Olson whose dedication to the production of this book is greatly appreciated. 


\section{CONTENTS}

Introduction - Antioxidant Nutrients and Immune Functions $\ldots \ldots \ldots \ldots \ldots$ A.Bendich

Cellular and Molecular Basis of Nutrition-Immunity Interactions

R.K. Chandra

The Role of Antioxidants in Modulating Neutrophil Functional Responses . . . . . 19 L.A. Boxer

Antioxidant Vitamins and Their Functions in Immune Responses . . . . . . . 35

A.Bendich

Antioxidants and the Aging Immune Response . . . . . . . . . . . 57

S.N. Meydani, M.Meydani, and J.B. Blumberg

Anti-inflammatory Systems in Human Milk . . . . . . . . . . . . . . . . . . . . 69

A.S. Goldman, Randall M. Goldblum, and Lars A. Hanson

The Administration of Beta Carotene to Prevent and Regress Oral Carcinoma in the Hamster Cheek Pouch and the Associated Enhancement of the Immune Response ........................... 77

J.L. Schwartz, G.Shklar, E.Flynn, and D.Trickler

Studies on Membrane Lipid Peroxidation in Omega-3 Fatty Acid-Fed

Autoimmune Mice: Effect of Vitamin E Supplementation

S.Laganiere, B.P.Yu, and G.Fernandes

Immunity and Disease Resistance in Farm Animals Fed Vitamin E Supplement . . . 103

R.P. Tengerdy

Possible Roles for Zinc in Destruction of Trypanosoma cruzi by Toxic

Oxygen Metabolites Produced by Mononuclear Phagocytes . . . . . . . . . . 111

J.M. Cook-Mills, J.J. Wirth, and P.J. Fraker

Effects of Copper Deficiency on the Immune System

J.R. Prohaska and O.A. Lukasewycz

Selenium and Glutathione Peroxidase: Essential Nutrient and Antioxidant

Component of the Immune System

J.E. Spallholz

Epilogue . . . . . . . . . . . . . . . . . . . . . . . . . . . . . 159

R.P. Tengerdy

Participants ........................... 163

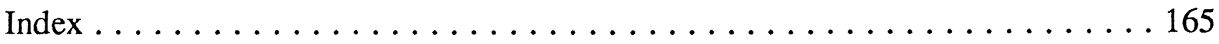

